\title{
The Role of Brand Community in Creating Loyalty
}

\author{
Ihwan Susila $^{1}$, Edy Purwo Saputro ${ }^{2}$, Pamula Mahardhika ${ }^{3}$ \\ \{ihwan.susila@ums.ac.id, e.purwo.saputro@ums.ac.id,pamulamahardhika45@gmail.com\} \\ Universitas Muhammadiyah Surakarta \\ Jl. A. Yani Tromol Pos I Pabelan Kartasura Surakarta 57162 Jawa Tengah Indonesia
}

\begin{abstract}
This study aimed to analyze factors that influence customer loyalty in automotive product. A survey was carried out on a sample of 162 automotive community members with purposive sampling technique. Data anlysis using structural equation modelling. The research model included several variables tested by SEM including selfcongruity, brand community effect, brand community trust, affective commitment, continuance commitment, repurchase intention, word-of-mouth communication, and constructive complain. The results indicate that brand affective commitment and brand continuence commitmen have important role in creating customer loyalty with different dimennsions. Self-congruity positively influnces repurchase intention mediated by continuance commitment. Brand community trust positively influences positive word-ofmouth communication and constructive complaint mediated by affective commitment.
\end{abstract}

Keywords: Brand loyalty, Brand Management, Brand Community

\section{Introduction}

Research in the field of marketing focus on brand community continues to grow [1], [2], [3]. In addition, the presence of internet network allows all members of the community to interact each other in a variety of social media platform and create a community [4], [5]. Consumers then easily compare one product to another by visiting the online community platform to ask questions or read the conversations that already exist made by other community members. Brand communities is an important antecedent to predict customer loyalty [5]. Marketers believe that facilitating the brand community has an efficient and effective cost to find new customers and retain the existing ones. Brand loyalty among marketing scholars can be seen as something special where consumers have a great psychological bond to the brand entity they consume. The influence of competitors have the potential switching cost of the consumer choices but if consumers have a deep commitment, they will continue to repurchase products or services they have used before [6].

Loyalty could not be created by overnight [6]. Provides economic benefits such as coupons, discounts, free service programs is dificult to increase consumer loyalty in various ways. It needs a holistic method which requires marketing strategies that can be adapted to various types of loyalty. Scholars understand that there are complex relational processes before consumers finally state loyalty to the product or service they use. According to Fullerton [7] loyalty is about what consumers feel about their relationship to a brand.

Empirical studies showed that commitment influences consumer loyalty [8], [9], [10]. Commitment can be defined as something inherent among parties who have desire to maintain a relationship [11], [12].

Previous research conducted by Ahn et al. [1] have placed commitment in setting the automotive brand community but as a unidimensional construct. This study will adopt the 
organizational commitment model initiated by Allen and Mayer [13] which consists of three components, namely affective, continuous, and normative commitment, in order to understand in more detail the dimensions of the commitment construct in relation to loyal behavior. But in this study only adopted affective commitment and continuity commitment only.

In general, in the field of marketing there are three components of commitment; normative, affective and continuous commitment [7]. In this study focus on affective and continues commitment. The reason not to include the normative component in this study because the effect of normative commitment is almost always heading in the same line with affective commitment and it has a weaker influence when both are tested in organizational literature [13]. Normative commitment is also usually highly correlated with affective commitment. Hence organizational behavior researchers question how differ the distinction between those two construct

In previous studies there have been studies of brand communities that examined commitment to brand loyalty in brand loyalty studies but were not examined it in the model created by Allen \& Mayer [14] which breaks down into two constructs of affective commitment and continuity commitment. Because commitment to consumers can be psychological or functional. Some scientists acknowledge commitment as a source of customer loyalty [7], [13], [12]. In previous studies trust and affect which has long been an antecedent of commitment in many previous studies. No studies examine the effect of selfcongruity on customer loyalty through commitment, this study put add self-congruity as an antecedent of commitment. According to Hur et al. [15) self-congruity variables are worth considering and testing as antecedents of commitment.

The purpose of this study is to analyze the relationship between self-congruity, brand community effect, brand community trust, affective commitment, continuance commitment, and loyalty dimension that represented by repurchase intention, positif word-of-mouth communication, and constructive complain. The study developed several hypotheses to explain the relationship betwen variables.

\section{Literature Review}

A brand community is a group of brand loyalists who are structurally constructed and are not limited to geographical areas. According to Sukoco and $\mathrm{Wu}$ [16) there are two main motivations that make a person motivated to join a brand community. The first is related to self-related motivation and the second is social-related motivation. Self-related motivation includes three elements such as knowledge, pleasure, and esteem. Knowledge refers to the consumer's interest to learn more about a product or to find solutions when facing problems the product they use. Pleasure is a feeling of happyness that attract and energizes someone to become a member of the brand community and esteem is a feeling in which members feel they have achievements when the brand community is successful because of involvement of themselve [16]. Social-related motivation is a person's interest in affiliation to build relationships with certain brand communities and obtain social status.

Commitment is consumer confidence in the current affective and functional benefits when to continue the existing relationships rather than terminate it [11]. The study conducted by and which focuses on the mediating role of community commitment which has identified this construct as positively affecting brand performance, such as brand loyalty. 
Repurchase intention is a consumer's decision to repurchase a particular service from the same company by considering their current situation. In this research, the interest in repurchasing is done by community members who have used previous products. Mosavi and Ghaedi [17] expressed the interest in repurchasing to provide acceptable proxies for actual buying behavior.

This study will explain multidimensional commitment in the model created by Allen \& Mayer [14] into two constructs of affective commitment and continuity commitment. Affective commitment is a deep consumer emotional relationship to a brand. Continunce commitment is a consumer relationship to a brand that is not deep because when they meet the perceive high switching costs and other alternatives that are more profitable they will switch brands

There are several reasons for encouraging members to join a brand community, such as knowledge, excitement and self-esteem [16] . Consumers participate in the Apple Newton community because they want to solve certain problems or learn new applications on these products [18]. Fun refers to feelings of pleasure that attract and energize someone to become a member of the brand community . Self-esteem refers to consumer interested in creating and maintaining self-concepts by participating in the brand community [16] such as for example building ideas for companies or products that are reflected in company management decisions.

\subsection{Self-Congruityand Commitment}

Self-congruity is the level of conformity between self-concept with the personality of users of a brand. The concept of self is how people look themselve regarding thoughts, perceptions and act [15] self-congruity is the behavior of consumers when they compare their image with the image of a store, product, and brand. Congruity theory according to Osgood and Tannenbaum [19] customers are more likely to have favorable attitudes and behaviors when they find objects or events that are in accordance with their beliefs. Social psychology researchers Osgood and Tannenbaum [19] asserted the impact of this congruity is evidenced by the quality of a positive relationship to produce a positive attitude such as satisfaction and affective commitment. In the context of consumer behavior, consumers who are emotionally bound to the product will predict their commitment to certain brand or object Emotional attachments are also predicted as consumer commitments.

There have been many studies on self-congruity in the area of products, brands, and stores [20]. The results of this study indicate that self-congruity influences consumer behavior both directly and indirectly through functional aspects of products, brands, or retail stores The results of image congruity research examined the role of functional store images in congruity theory on store loyalty found that the functional store image mediated the relationship between congruity and store loyalty. There is a positive relationship between self-congruity and behavioral intention. Continuence Commitent is one of the characteristics of brand and consumer relations [7]. Consumers consume a brand repeately because they find the personality of a brand in accordance with the interpretation of their personalities attached to consumers through action, use and consumption. Research Lee \& Lee [21] found that there is a positive relationship between self-congruity and repurchase intention, considered that repuchase intention includes dimensions of behavioral intention.

H1a. There is a positive relationship between self-congruity and affective commitment $\mathrm{H} 1 \mathrm{~b}$. There is a positive relationship between self-congruity and continuance commitment H2a. There is a positive relationship between community effect and affective commitment $\mathrm{H} 2 \mathrm{~b}$. There is a positive relationship between community effect and continuance commitment H3a. There is a positive relationship between community trust and affective commitment 
$\mathrm{H} 3 \mathrm{~b}$. There is a positive relationship between community trust and continuance commitment

\subsection{Commitment and Loyalty}

The dimension of consumer loyalty consists of three model variables that have been used by Hur et al. [15] consist of repurchase intention, word-of-mouth of brand, and constructive complaint of brand. In the research only repurchase intention would be adopted as consumer loyalty dimension. Affective commitment can be said to be a stage where consumers are considered loyal because they are pleasant about the product or service and always buy the brand [7]. Brand community is a bridge in this process where consumers share identification of the brands they use. Brand loyalty occurred when consumers have a deep commitment to repurchase or subscribe even though faced with choices that trigger switching behavior. Whereas repurchase intention is one dimension of brand loyalty [15]

$\mathrm{H} 4 \mathrm{a}$. There is a positive relationship between affective commitment and repurchase intention $\mathrm{H} 4 \mathrm{~b}$. There is a positive relationship between affective commitment and word-of-mouth communication.

H4c. There is a positive relationship between affective commitment and constructive complain

If consumers have a continuence commitment they will be hard to leave because of the few alternatives better available [7]. Brand community identification can produce commitment to the brand community, psychological ties that describe harmony between members 14]. Experience and shared values are the basis for creating brand community identification In the context of the community, for example, there are people who buy Isuzu Panther not because they love Isuzu Panther, but they are considering a multi-point vehicle that has strong durability, efficient fuel consumption, and an affordable price compared to rivals. Incidentally in Indonesia there is a panther mania community which is a forum for those users of Isuzu Panther. Because they already have Isuzu Panther they use the momentum to join the community to get functional benefits in the community for example in terms of car repair or because they want to make new friends because in the community there are many experts and experiences that can be shared by other community members. After they feel that they are benefiting from the functionality they get from the community they will think about buying a panther because of the ease of information if there is a problem with their car. There is a concern to speculate (side-bet) to move to another product. Identification in the brand community can be translated that community members will likely buy the same brand, share their brand experience, and get the same functional utilization from consuming the same brand. H5a.There is a positive relationship between continuance commitments and repurchase intention $\mathrm{H} 5 \mathrm{~b}$. There is a positive relationship between continuance commitment and word-ofmouth communicationH5c. There is a positive relationship between continuance commitment and constructive complain

\section{Method}

The object of this research is Panther Mania Community members. This community has been officially established since 2009, which was initiated by the interaction among members in panther-mania@yahoogroups.com. Eight years later the community achieve more than 1200 members. The Panther Mania community accommodates all types of Panther MPV (multi point vehicle) models or pick-ups as well. 
Data for the study were collected from a survey of 162 (155 males and 7 female) members of panther mania community. There were three catagories of characteristic data gender, education and duration. The majority of respondents were graduate education of 96 with a percentage $(59.3 \%)$. Then there were 37 high schools or $22.8 \%$ and 29 junior high school graduates or $17.9 \%$. The respondents chosen for this study had joined to this club for at least one year. Therefore it was expected they have participated in a series of activities ranging from local, provincial and national scale hence that they can take impressions while participating in these activities. Most respondents who have joined the Panther Mania club for more than three years with 66 percentages (40.7\%). Data collection was carried out by distributing questionnaires with random sampling using Google forms and were shrared to Whatsapp group of Panther Mania anniversary and through Facebook Direct Message assisted by Panther Mania founder Heri Siswanto and Panther Mania Decade Secretariat Joko Lasono, and all members friends of Panther Mania Community. All items in this study was translated into Indonesian so that could be understood by respondents. The study ran about two months before fasting until approaching the feast of 2019. The quistionnaire consisted of two sectionone section wasdevoted to questions related demographic information, whereas the second consisted of items related to all study constructs.

Table 1. Respondent Profile

\begin{tabular}{llll}
\hline Details of respondent $(n=162)$ & Frequency $(\mathrm{s})$ & $\%$ \\
\hline Education & Middle cchool & 29 & $17.9 \%$ \\
& High school & 37 & $22.8 \%$ \\
& Graduate & 96 & $59.3 \%$ \\
Gender & Male & 155 & $95.7 \%$ \\
& Female & 7 & $4.3 \%$ \\
& One year & 22 & $13.6 \%$ \\
& Two years & 42 & $25.9 \%$ \\
& Three years & 32 & $19.8 \%$ \\
& More than three years & 66 & 40.7 \\
\hline
\end{tabular}

\section{Validity and Reliability}

Validity test related to the accuracy of a measurement that aims to assess a set of measurement indicators on the model truly reflects the latent construct of the model. The results of testing the size of a model through construct validity provide confidence that the size of items taken from the sample represents the actual score in the population. The construct validity is said to be valid if the standardized loading factor value is $\geq 0.45$ (Hair et al., 2014). The validity test using factor analysis shows that all indictors have loading factor more than 0.6 and also the reliability test shows that all the constructs have Cronbach's alpha more than 0.8. This shows that all indicators and variables can use as measurement for the latent construct.

Table 2. Factor loadings, construct reliability, and variance extracted

\begin{tabular}{|c|c|c|c|c|}
\hline & Factors & $\begin{array}{l}\text { Factor } \\
\text { Loadings }\end{array}$ & $\begin{array}{l}\text { Construct } \\
\text { Reliability }\end{array}$ & $\begin{array}{l}\text { Variance } \\
\text { Extracted }\end{array}$ \\
\hline \multicolumn{3}{|c|}{ Self-Congruity } & 0.859 & 0.877 \\
\hline 1 & $\begin{array}{l}\text { The characters of the Panther Mania members are } \\
\text { more or less the same as me }\end{array}$ & .733 & & \\
\hline 2 & $\begin{array}{l}\text { The activities in Pnther Mania reflect my who like } \\
\text { touring and hanging out with friends }\end{array}$ & .788 & & \\
\hline 3 & $\begin{array}{l}\text { Panther Mania suits me as a family because it is a } \\
\text { community car for families }\end{array}$ & .661 & & \\
\hline
\end{tabular}


4 The cars of Panther Mania members become to modify my own car

\section{Brand Community Affect}

1 I was happy when I got a new brother in Panther

Mania

2 Joining the panther mania community made me

love my Isuzu panther even more

3 I am happy when participating in various activities at Panther Mania

4 When I can participate in the panther mania I am happy

\section{Brand Community Trust}

I believe I will get a solution from my friends Panther Mania if I have problems with my car

2 believe that by following the Panther Mania I get a new family

3 Panther Mania is a trusted car community for Isuzu Panther users

4 I believe that by following the panther mania of automotive science I have improved

5 feel calmer when traveling when there are problems because my friends are willing to help

\section{Brand community affective commitment}

1 I feel that I have a close friendship with the extended Panther Mania family

2 Panther Mania gives great meaning to channelling my love towards my Isuzu Panther

3 I feel Panther Mania is a car community that fits my personality who likes a tough and economical diesel car

4 Because Panther Mania is one of big car communities in Indonesia, I am proud to have joined Mania 0.78 in various places

2 I will exchange opinions or any information when gathering with other members not only about the car

3 If I leave Panther Mania, I will not find a better Isuzu Panther community

4 If I leave Panther Mania it will be more difficult for me to ask about the Isuzu Panther

\section{Repurchase Intention}

1 If have more money I want to replace my current Isuzu Panther with a younger year

2 Despite Panther diesel engine technology is not common rail, I will still buy Panther because it is fuel efficient and maintenance is easy and inexpensive

3 If the Panther diesel engine technology changes to a common rail technology I will buy or replace my 
Panther with a new one

4 If I have more money, I will buy one more Isuzu Panther besides the old one

.686

Word-of-Mouth Communication

0.887

0.915

1 I often tell about the advantages of Isuzu Panther to my friends or relatives

2 I recommend Isuzu Panther to people who will buy $\quad .769$

a car

3 I will give a positive comment about how I felt

while using Isuzu Panther both in the real world

and on social media

4 I would recommend a specialist workshop for Isuzu

Panther to my friend and relatives

Constructive Complaint

.781

.820

.796

.752

.752

$0.922 \quad 0.986$

through social media or a comment column for

Isuzu Astra Motor Indonesia for improving Isuzu

Panther in the future.

2 I will convey on the fan page on Facebook or

WhatsApp Panther Mania or to Isuzu regarding the problems that I have encountered in my Isuzu Panther.

3 When there is a production defect or a downgrade (decrease in quality or quantity) with the panther I bought, I will give a constructive complaint to Isuzu Astra Motor Indonesia

$4 \quad$ I will give advice to Isuzu Astra Motor Indonesia (IAMI) so as not to stop the production of Isuzu Panther in Indonesia because the car is a legend in the family diesel car in this country

5 I want Isuzu Astra Motor Indonesia (IAMI) to provide a diesel common rail variant on the domestic market

\section{Result And Discussion}

Data analysis using structural equation modeling (SEM) shows results that supported and unsupported the proposed hypothesis (Table. 3). Goodness of fit indexes including Chi Square, Probability, GFI, AGFI, RMSEA show good suitability index (Figure 1). Hypothesis test results can be explained following the hypothesis statements 1 to 12 . Firstly, selfcongruity does not affect the brand community affective commitment with the estimated coefficient positive 0.016 and critical ratio less than $2(\mathrm{E}=+.016 ; \mathrm{CR}=.333)$. The suitability of the members of the panther mania apparently did not make them have an affective commitment to this club. This means that when club members compare their suitability to the activities in Panther Mania it does not make them have the belief that by following Panther Mania will make them feel there is a big brotherhood, there will be a place to channel their love for Isuzu Panther, and feel confident that the car club diesel like this they want. If emphasizing from the emotional side there is a similarity between the construct of affective commitment with the construct of emotional image. Emotional attachment is estimated to be a commitment from consumers. The direct effect shows that self-congruity has no effect on 
repurchase intention, word-of-mouth communication, and constructive complaints either directly or through brand community affective commitment.

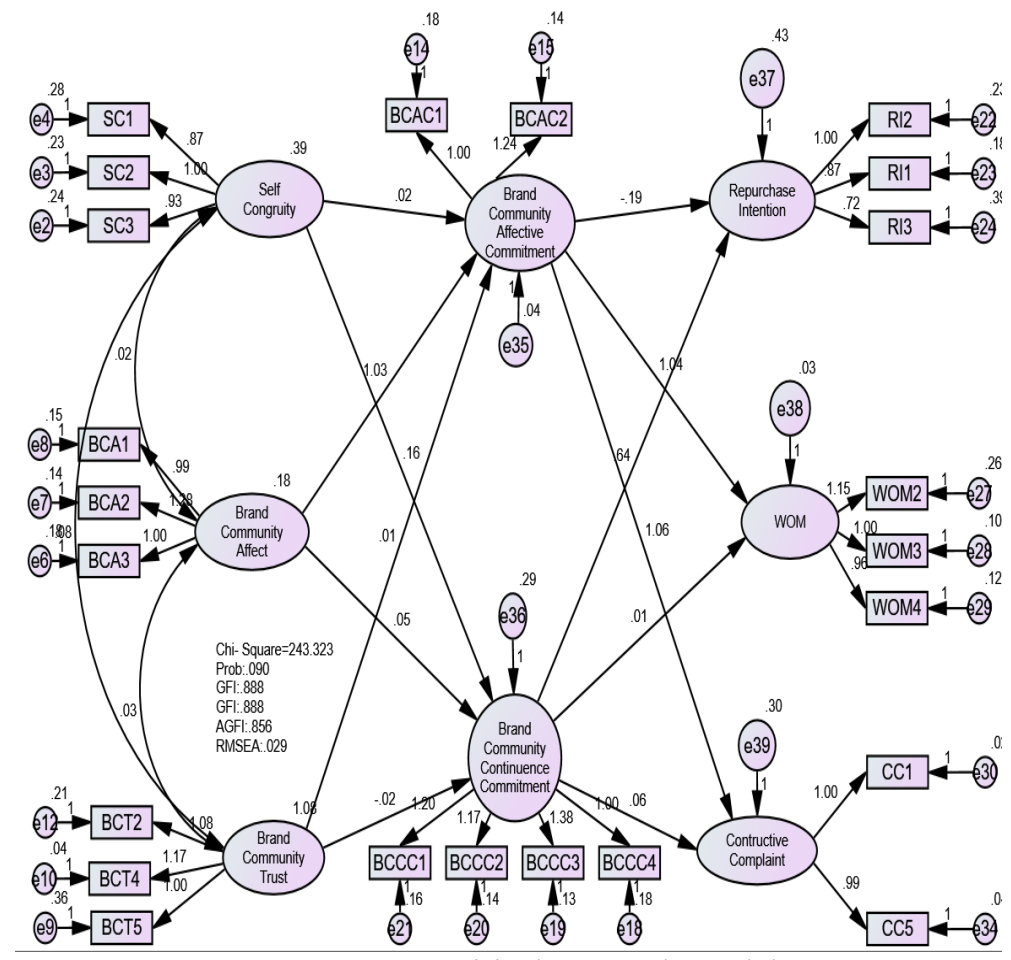

Fig.1. Empirical Research Model

Secondly, self-congruity affects brand community continuity commitment $(\mathrm{E}=+.163$; CR $=1,968$. There is no direct effect of self-congruity on repurchase intention. Self-congruity will end in repurchase intention through the brand community continuity commitment. Furthermore, self-congruity has no effect on, WOM, and constructive complaints either directly or through brand community continuity commitment. The level of suitability of club members did not make them transmit positive things about Isuzu Panther, and constructive criticism of Isuzu. But with their self-sufficiency towards Panther Mania can make them have the intention to buy Isuzu Panther with the support of their commitment rationally.

Thirdly, brand community influence influences brand community affective commitment (E $=+1,026 ; \mathrm{CR}=7,677$ ). There is a positive relationship between affective brand experience and affective brand attachment. Where the affective brand is more emphasis on the emotional side. There is no direct influence of brand community effect on WOM with. Brand community affect will positively influence WOM through brand community continuity commitment. There is no direct effect of brand community effect on constructive complaint with. Brand community affect has a positive effect on WOM and constructive complaints through brand community affective commitment. But brand community affect has no effect on repurchase intention either directly or through the brand community affective commitment. However, a positive response can make club members have an impact on their willingness to convey any 
positive impression about Isuzu Panther, and be able to make them willing to give criticism and suggestions to Isuzu but not directly have to be helped with affective commitment.

Table 3. Regression Weight

\begin{tabular}{|c|c|c|c|c|c|c|}
\hline & & & Estimate & S.E. & C.R. & $\mathrm{P}$ \\
\hline $\begin{array}{l}\text { Brand Community } \\
\text { Affective-Commitment }\end{array}$ & $<---$ & Self-Congruity & .016 & .048 & .333 & .739 \\
\hline $\begin{array}{l}\text { Brand Community } \\
\text { Affective- } \\
\text { Commitment }\end{array}$ & $<---$ & Brand Community Affect & 1.026 & .134 & 7.677 & $* * *$ \\
\hline $\begin{array}{l}\text { Brand Community } \\
\text { Affective-Commitment }\end{array}$ & $<---$ & Brand Community Trust & .009 & .027 & .337 & .736 \\
\hline $\begin{array}{l}\text { Brand Community } \\
\text { Continuance- } \\
\text { Commitment }\end{array}$ & $<--$ & Self-Congruity & .163 & .083 & 1.968 & $* * *$ \\
\hline $\begin{array}{l}\text { Brand Community } \\
\text { Continuance- } \\
\text { Commitment }\end{array}$ & $<---$ & Brand Community Affect & .054 & .115 & .471 & .638 \\
\hline $\begin{array}{l}\text { Brand Community } \\
\text { Continuance- } \\
\text { Commitment }\end{array}$ & $<---$ & Brand Community Trust & -.018 & .044 & -.421 & .674 \\
\hline Repurchase Intention & $<---$ & $\begin{array}{l}\text { Brand Community } \\
\text { Affective-Commitment }\end{array}$ & -.194 & .129 & -1.498 & .134 \\
\hline WOM & $<---$ & $\begin{array}{l}\text { Brand Community } \\
\text { Affective-Commitment }\end{array}$ & 1.042 & .103 & $\begin{array}{l}10.16 \\
5\end{array}$ & $* * *$ \\
\hline $\begin{array}{l}\text { Constructive } \\
\text { Complaint }\end{array}$ & $<---$ & $\begin{array}{l}\text { Brand Community } \\
\text { Affective-Commitment }\end{array}$ & 1.055 & .131 & 8.038 & $* * *$ \\
\hline Repurchase Intention & & $\begin{array}{l}\text { Brand Community } \\
\text { Continuance-Commitment }\end{array}$ & .639 & .123 & 5.207 & $* * *$ \\
\hline WOM & $<---$ & $\begin{array}{l}\text { Brand Community } \\
\text { Continuance-Commitment }\end{array}$ & .007 & .051 & .133 & .894 \\
\hline $\begin{array}{l}\text { Constructive } \\
\text { Complaint }\end{array}$ & $<---$ & $\begin{array}{l}\text { Brand Community } \\
\text { Continuance-Commitment }\end{array}$ & .056 & 091 & .613 & .540 \\
\hline
\end{tabular}

Fourth, brand community affect has no effect on brand community continuity $(E=+.054$; $\mathrm{CR}=.115$ ). The level of positive response from members does not make members have a rational commitment. In this study it was different from previous studies. There is a positive relationship between brand experience and cognitive brand attachment where continuity commitment also emphasizes cognitive aspects. Brand community affect also does not directly influence repurchase intention, WOM and constructive complaints or through brand community continuity commitment.

Fifth, Brand community trust has no effect on brand community affective commitment (E $=+.009 ; \mathrm{CR}=.337)$. The trust that members have in the club hasn't been able to make them emotionally committed. The relationship of trust and affective commitment is rejected. Brand community trust also does not directly influence repurchase intention, WOM and constructive complaints or through brand community affective commitment.

Sixth, brand community trust has no effect on brand community continuity commitment (E $=-.018 ; \mathrm{CR}=-.421$ ). Previous studies have stated positive relationships between trust and commitment. However in this study shows the trust that members have in the club has not been able to make them commit to the rational aspects. Brand community trust also does not 
directly influence repurchase intention, WOM and constructive complaints or through brand community continuity commitment.

Seventh, brand community affective commitment has no effect on repurchase intention (E $=-194 ; \mathrm{CR}=-1.498)$. This research shows that the more members have affective commitment, the less they have the intention to buy Isuzu Panther again. In many previous studies stated that someone who is emotionally bound will repurchase the product they love. But not in this study. There are two possibilities first, maybe consumers already love their cars and have invested a lot of modifications and are reluctant to replace them. The second could be that consumers are currently in the wait and see stage not to buy new units because there has been no significant change after nearly 20 years.

Eighth, brand community affective commitment affects WOM Communication $(\mathrm{E}=+$ $1,042 ; \mathrm{CR}=10,165)$. The more members have an affective commitment the more they are willing to share positive stories about the Isuzu Panther. Affective commitment gives the biggest contribution to WOM in this study, followed by constructive complaint, but it has no effect on repurchase intention.

Ninth, brand community affective commitment affects constructive complaints $(\mathrm{E}=+$ 1,$055 ; \mathrm{CR}=8,038$ ). The more members have an affective commitment the more they want to provide input to Isuzu so that the Isuzu Panther going forward will be better. In the study of Hur et al [15] unidimensional commitment gave a positive effect on constructive complaints even though the contribution was the least compared to repurchase intention and WOM. However, in this study the opposite happened. Affective commitment made a greater contribution than constructive complaints than to WOM.

Tenth, brand community continuance commitment affects repurchase intention $(\mathrm{E}=+$. 639; $\mathrm{CR}=5$,207). The results of this study are in accordance with Fullerton [7] with the conscientious object consumers of GAP apparel products. So brand community continuity commitment gives the biggest contribution to repurchase intention than WOM and constructive complaints. This research shows that consumers are willing to buy this car not with an emotional impulse but with an encouraging rational commitment. In a sense at this stage they buy a car because it is tied to its functionality and economic value. Proved that the Panther is a medium car Multi-Purposed Vehicle (MPV) which has a large capacity of haulage and performance while still saving fuel and the price of spare parts which is very affordable when compared to the large capacity of the car.

Eleventh, brand community continuance commitment has no effect on WOM Communication $(\mathrm{E}=+.007 ; \mathrm{CR}=.133)$. The results of this study are in agreement with many previous studies. The functional advantages they can get while using Isuzu Panther do not make them interested in sharing positive stories with others.

Twelfth, continuous community brand commitment has no effect on constructive complaints $(\mathrm{E}=+.056 ; \mathrm{CR}=.613)$. This is different from the research of Hur et al. [15] stated there was a positive relationship between brand commitment and constructive complaints. This level of continuity commitment does not make club members interested in contributing to the company through constructive advice. Some previous studies which prove the effect of continuity commitment is smaller than affective commitment on behavioral intentions. 


\section{Conclusion}

This research showed that consumers who have emotional and functional benefits from a community will have a loyalty in automotive product. Brand community trust have an important role in creating loyalty. This relationship mediated by affective commitment. In addition, the emotional benefits not only obtained from a community but also from the brand that figure out by affective commitment. Therefore, automotive companies need to improve relationships with the automotive owner community. In addition, to improve a long-term relationship with the brand, companies need to improve product quality to enhance the company's image. The automotive company need to improve their product specifically in technology to compete with competitors such as environmentally friendly technology that meets Euro 4 environmental emissions standards. Future research needs to focus on how maintain the customer loyalty and attempt to identify the role of brand equity in this relationship.

\section{References}

[1] Ahn, H., Kwon, M.W., and Sung, Y. Online Brand Community across Cultures: A Comparison between the US and Korea, International Journal of e-Business Management, 4, (1). pp. 34-52 (2010). doi: 10.3316/IJEBM0401034

[2] Lobschat, L., Zinnbauer, M.A., Plaas, F., and Joachimstaler, E.: Why Social Currency Becomes a Key Driver of a Firm's Brand Equity - Insights from the Automotive Industry, 46 (1-2), pp. 125148 (2013).

[3] Essamri, A., McKechnie, S., and Winklhofer, H.: Co-creating corporate brand identity with online brand communities: A managerial perspective, Journal of Business Research, 96, pp. 366375 (2019)

[4] Sung, Y., Kim, Y., Kwon, O., and Moon, J.: An Explorative Study of Korean Consumer Participation in Virtual Brand Communities in Social Network Sites, Journal of Global Marketing, 23 (5), pp. 430-445 (2010)

[5] Zheng, X., Cheung, C.M.K., Lee, M.K.O., and Liang, L.: Building brand loyalty through user engagement in online brand communities in social network sites, Information Technology \& People, 28 (1), pp. 90-106 (2015).

[6] Shaomian, A., and Bob, H.: The path to loyalty among theatre patrons: The importance of interaction and a sense of brand community. Journal of the Music \& Entertainment Industry Educators Association, 15 (1), 13-35 (2015).

[7] Fullerton, G.: The Impact of brand commitment on loyalty to retail service brands. Canadian Journal of Administrative Sciences, 22 (2), 97-110 (2005)

[8] Rauyruen, P., and Miller, K.E.: Relationship quality as a predictor of B2B customer loyalty, Journal of Business Research, 60 (1), pp. 21-31 (2007)

[9] Robert, K., Varki, S., and Brodie, R.: Measuring the quality of relationship in consumer services: an empirical study, European Journal of Marketing, 37 (1/2), pp. 169-196 (2003). https://doi.org/10.1108/03090560310454037

[10] Walsh, G., Henning-Thurau, T., Sassenberg, K., and Bornemann, D.: Does relationship quality matter in e-service? A comparison of online and offline retailing, Journal of Retailing and Consumer Services, 17 (2), pp. 130-142 (2010)

[11] Moorman, C., Zaltman, G., Deshpande, R.: Relationships Between Providers and Users of Marketing Research: The Dynamics of Trust Within and Between Organizations. Journal of Marketing Research, 29, pp. 314-329 (1992) 
[12] Morgan, R.M., and Hunt, S.D.: The commitment-trust theory of relationship marketing, Journal of Marketing, 58, pp. 20-38 (1994)

[13] Allen, N., and Meyer, J.P.: Affective, Continuance, and Normative Commitment to the Organization: An Examination of Construct Validity, Journal of Vocational Behavior, 49 (3), pp. 252-276 (1996)

[14] Allen, N.J., and John P. Meyer, J.P.: The Measurement and Antecedents of Affective, Continuance and Normative Commitment to the Organization". Journal of Occupational Psychology 63:1-18 (1990)

[15] Hur, W., Ahn, K., and Kim, M.:Building brand loyalty through managing brand community commitment, Management Decision, 49 (7), pp.1194-1213 (2011)

[16] Sukoco, B.M., and $\mathrm{Wu}, \mathrm{W} .:$ The personal and social motivation of customers' participation in brand community, African Journal of Business management, 4 (5), pp. 614-622 (2010)

[17] Seyed Alireza Mosavi, S.A., and Ghaedi, M.: A survey on the relationship between trust, customer loyalty, commitment and repurchase intention, African Journal of Business Management, 6 (36), pp. 10089-10098 (2012)

[18] Muniz, A.M., and Schau, H.J.: Religiosity in the Abandoned Apple Newton Brand Community, 31 (4), pp. $737-747$ (2005)

[19] Osgood, C.E., and Tannenbaum, P.H.: The principle of congruity in the prediction of attitude change. Psychological Review, 62, 42-55 (1955)

[20] Jamal, A. and Goode, M.M.H. (2001), "Consumers and brands: a study of the impact of selfimage congruence on brand preference and satisfaction", Marketing Intelligence \& Planning, Vol. 19 No. 7, pp. 482-492 2001). https://doi.org/10.1108/02634500110408286

[21] Lee, J. and Lee, Y.: The interactions of CSR, self-congruity and purchase intention among Chinese consumers. Australasian Marketing Journal, 23(1), 19-26, (2015) 